\title{
TINGKAT KEBUGARAN JASMANI ANGGOTA UKM FUTSAL UNIVERSITAS TEKNOKRAT INDONESIA
}

\author{
M. Vani Aprilianto ${ }^{1}$, Eko Bagus Fahrizqi ${ }^{2}$ \\ Universitas Teknokrat Indonesia ${ }^{1,2}$ \\ m.vaniaprilianto.2015@gmail.com ${ }^{1}$ \\ eko.bagus@teknokrat.ac.id ${ }^{2}$
}

\begin{abstract}
Sports Activity is related to achievements that is inseparable from some factors and one of them is physical fitness. Following the physical fitness by the members of Futsal Club Universitas Teknokrat Indonesia is unknown. This research aims to reveal the level of physical fitness of the members of Futsal Student Activity Universitas Teknokrat Indonesia, with 29 members involved. The data collecting technique uses the instrument of TKJI that consists of 5 tests that are: 50 meters Running Test, Push Up, Sit Up, Vertical Jump, Run 1.2 Kilometers, the data analyzing technique of this research uses the descriptive statistics analysis with percentage. The result shows that the level of physical fitness of Futsal Club Universitas Teknokrat Indonesia, 5 students $(17,24 \%)$ classified as good, 20 students $(68,96 \%)$ classified as average, 4 students $(13,79 \%)$ classified as deficient, and there are no students that classified great and awful. Hence, the result of the physical fitness level test towards the members of Futsal Club Universitas Teknokrat Indonesia can be classified as average.
\end{abstract}

Keywords: Physical Fitness, Test, Run, Push Up, Sit Up, Vertical Jump

\begin{abstract}
Abstrak
Aktivitas Olahraga berkaitan dengan prestasi yang tidak lepas dari beberapa faktor dan salah satu diantaranya adalah kebugaran jasmani. Terkait dengan kebugaran jasmani yang dimiliki oleh anggota UKM Futsal Universitas Teknorat Indonesia belum diketahui. Adapun tujuan penelitian ini adalah untuk mengetahui Tingkat Kebugaran Jasmani anggota UKM Futsal Universitas Teknorat Indonesia. Penelitian ini adalah penelitian deskriptif yang menggunakan metode survei. Subyek dari penelitian ini adalah anggota UKM Futsal Universitas Teknorat Indonesia, dengan jumlah 29 anggota. Teknik pengambilan data pada penelitian ini menggunakan instrumen TKJI yang terdiri dari 5 item tes yaitu: Tes lari 50 meter, Pull up, Sit Up, Vertical Jump, lari 1,2 KM. Teknik analisis data yang digunakan dalam penelitian ini adalah analisis statistik deskriptif dengan persentase. Hasil penelitian menunjukkan bahwa Tingkat Kebugaran UKM Futsal Universitas Teknorat Indonesia yaitu klasifikasi Baik sebanyak 5 orang $(17,24 \%)$, klasifikasi sedang sebanyak 20 orang $(68,96 \%)$, dan klasifikasi kurang sebanyak 4 orang $(13,79 \%)$, dan tidak ada siswa yang memiliki klasifikasi baik sekali dan kurang sekali. Dengan demikian, hasil tes tingkat kesegaran jasmani pada Anggota UKM Futsal Universitas Teknokrat Indonesia dapat dikategorikan sedang.
\end{abstract}

Kata Kunci: Kebugaran Jasmani, Tes, Lari , Push Up, Sit Up, Vertical Jump

\section{To cite this article:}

Aprilianto, Muhammad Vani dan Fahrizqi, Eko Bagus. (2020). Tingkat Kebugaran Jasmani Anggota Ukm Futsal Universitas Teknokrat Indonesia. Journal Of Physical Education. 1 (1), 1-9 


\section{PENDAHULUAN}

Olahraga adalah sebuah aktivitas hidup yang paling digemari. Olahraga merupakan satu kebutuhan hidup yang tidak dapat ditinggalkan. Sebuah aktivitas olahraga harus dilakukan secara kontinu dan selaras. Aktivitas olahraga dapat dilakukan oleh siapapun karena tidak memandang ras, agama maupun tingkatan sosial. Pada zaman Romawi kuno terdapat slogan yang begitu dipopulerkan oleh masyarakat yakni "MENS SANA IN CORPORE SANO". Slogan tersebut menjadi suatu semangat dalam bidang olahraga dan kesehatan yakni ketika seseorang menggeluti aktivitas olahraga. Kemudian slogan tersebut dimaknai oleh masyarakat, bahwa "Di dalam tubuh yang kuat terdapat jiwa yang sehat".

Tersirat dari pemikiran ini peneliti mencoba mencari batasan mengenai esensi atau apa yang sebetulnya tentang hakekat dari olahraga itu sendiri yang dapat di kutip dari definisi-definisi oleh para pakar dan ilmuan olahraga. Gumantan (2019) Menyatakan Kegiatan olahraga permainan di sekolah yang diberikan oleh guruguru bidang studi pendidikan jasmani akan banyak membantu pertumbuhan dan perkembangan anak secara menyeluruh. Artinya kegiatan olahraga permainan dapat memberikan dampak positif terhadap unsur-unsur jasmaniah, kejiwaan dan sosial

Kemudian definisi mengenai apa dari sebetulnya olahraga ini dijadikan alat analisis secara teoritik dalam membahas permasalahan dalam penelitian ini. Definisi dan pengertian dari olahraga yang penulis kutip di antaranya dapat dijelaskan di paragraf berikut :

Giriwijoyo (2007) menjelaskan bahwa Olahraga adalah serangkaian gerak raga yang teratur dan terencana untuk memelihara gerak (mempertahankan hidup) dan meningkatkan kemampuan gerak (meningkatkan kualitas hidup). Sama dengan pernyataan lainnya Mutohir (2004) menjelaskan bahwa Olahraga yang dilakukan secara sistematis, teratur dan terarah akan sangat membantu upaya kita menciptakan pola hidup sehat yang sehat dan berkualitas.

Dari penjelasan olahraga di atas terdapat pula ciri-ciri olahraga menurut Lutan (1991) menjelaskan ciri khas olahraga yaitu:

1. Olahraga berorientasi pada kegiatan jasmani dalam wujud keterampilan motorik, daya tahan, kekuatan dan kecepatan. Dalam olahraga unsur jasmani yang sangat dominan.

2. Olahraga sebagai sebuah realitas, olahraga dilakukan dalam suasana yang tak sebenarnya, tetapi keterlibatan seseorang dalam olahraga merupakan sesuatu yang nyata.

3. Prinsip prestasi dalam olahraga, tanda-tanda prinsip prestasi dalam olahraga ialah:

a. Peragaan kemampuan jasmani, hingga tingkat maksimal.

b. Kegiatan olahraga dilaksanakan secara maksimal.

c. Tidak bertujuan untuk menghancurkan lawan.

4. Aspek sosial dari olahraga, olahraga yang dilakukan akan terjadi sebuah interaksi sosial dan akan membentuk kelompok sosial.

Pengertian Olahraga menurut International Council of Sport and Physical Education (ICSPE) yang dikutip oleh Lutan (1991) yaitu:

1. Setiap kegiatan fisik yang mengandung sifat permainan dan berisi perjuangan dengan diri sendiri atau dengan orang lain, atau konfrontasi dengan unsur-unsur alam disebut olaharaga.

2. Kalau kegiatan ini meliputi juga pertandingan, maka kegiatan itu harus dilaksanakan dengan semangat/jiwa sportif. Tidak mungkin ada olahraga dalam arti sebenarnya tanpa isi "fair play".

3. Olahraga seperti dinyatakan di atas merupakan alat pendidikan yang ampuh

Dan dari penjelasan di atas tersebut bisa disimpulkan bahwa olahraga merupakan suatu kegiatan jasmani yang sangat dominan, merupakan sesuatu yang nyata, terdapat prinsip prestasi dan membentuk kelompok sosial. Di dalam kurikulum pendidikan jasmani diharapkan memiliki kebugaran jasmani yang memadai, menguasai paling tidak salah satu nomor atletik, senam, beladiri, renang, dan olahraga permainan sehingga peserta didik mempunyai kepercayaan diri untuk melakukan kegiatan olahraga secara teratur, memiliki gaya hidup aktif karena didukung oleh pengetahuan yang memadai tentang pendidikan jasmani, peraturan teknis dan taktis serta strategi olahraga (Yuliandra, 2019).

Faktor kebugaran jasmani dan komponen motorik yang baik haruslah dimiliki oleh setiap pemain atau atlet untuk menunjang performanya. Jika Proses motorik adalah gerakan yang langsung melibatkan otot untuk bergerak dan proses persyaratan yang menjadikan seseorang mampu menggerakkan anggota tubuh (tangan, kaki, dan anggota tubuh) (Mahfud dan Fahrizqi, 2020). 
Maka Seorang pemain futsal dapat mencapai kesuksesan apabila pemain tersebut memiliki empat faktor, yaitu; faktor genetik atau keturunan, faktor kedisiplinan, faktor latihan, dan faktor keberuntungan. Untuk mencapai hal tersebut tidaklah mudah. Perlu mengambil langkah-langkah kongkrit untuk menunjang terhadap peningkatan pretasi perfutsalan. Langkah-langkah yang perlu dilakukan diantaranya yaitu pelatihan, peningkatan pengadaan prasarana dan sarana, permasalahan, pemanduan bakat, peningkatan kualitas pembinaan dan sebagainya. Teknik dasar permainan futsal menentukan sampai dimana seorang pemain dapat meningkatkan mutu permainannya (Fahrizqi, 2019).

\section{TELAAH PUSTAKA . Kebugaran Jasmani}

Kebugaran Jasmani merupakan satu hal yang dapat mempengaruhi dalam pencapaian prestasi suatu atlet. Kebugaran Jasmani yang tangguh dan baik jika dilatih secara terus menerus akan semakin lebih baik dalam pencapaian prestasi. Kebugaran jasmani merupakan salah satu aspek dari Komponen Kondisi Fisik . Dimana kondisi fisik merupakan pondasi untuk meraih prestasi bagi semua atlet. Teknik, mental dan taktik akan dapat dikembangkan dengan baik jika memiliki kualitas fisik yang baik. Pendapat yang dikemukakan Sajoto (1988), kondisi fisik adalah satu prasyarat yang sangat diperlukan dalam usaha peningkatan prestasi seorang atlit, bahkan dapat dikatakan sebagai dasar landasan titik tolak suatu awalan olahraga prestasi. Kondisi fisik dapat mencapai titik optimal jika dimulai sejak usia dini dan dilakukan secara terus menerus sepanjang tahun dengan berpedoman pada prinsip-prinsip dasar latihan. Di samping itu, perkembangan fisik harus direncanakan secara periodik berdasarkan tahapan latihan, status kondisi fisik atlet, faktor-faktor lain, seperti gizi, fasilitas, alat, lingkungan dan status kesehatan atlet (Fahrizqi, 2019).

Untuk mencapai kebugaran jasmani yang baik seorang atlet harus memiliki komponen dasar dari aspek jasmani. Senada dengan Bompa (1994) dalam Irianto (2002), mengemukakan bahwa komponen dasar dari biomotor olahragawan ada 5 yaitu: kekuatan (strength), daya tahan (endurance), kecepatan (speed), kelentukan (flexibility) dan koordinasi (coordination). Adapun komponen-komponen yang lain merupakan perpaduan dari beberapa komponen sehingga membentuk satu peristilahan sendiri. Beberapa komponen kondisi fisik yang diperlukan dan mempengaruhi kemampuan passing atau mengoper bola, diantaranya yaitu panjang tungkai, kekuatan otot tungkai, lingkar paha kekuatan tung kai,dan koordinasi kaki. Berdasarkan uraian di atas peneliti ingin mengetahui tentang kemampuan ketepatan jarak jauh khususnya pula aspek fisiknya (Fahrizqi , 2019).

Dari sepuluh komponen kondisi fisik yang perlu diperhatikan lebih dan ditingkatkan lebih untuk meningkatkan prestasi atlet sepakbola dalam penelitian ini. Sedangkan komponen komponen kondisi fisik yang akan digunakan dalam penelitian ini yaitu: kekuatan yang meliputi, Power otot tungkai,kekuatan ketahanan otot perut, kekuatan dan ketahanan otot lengan, kecepatan (speed), daya tahan aerobik, Dari kelima komponen tersebut dapat dijelaskan sebagai berikut:

1) Kecepatan

Kecepatan sangat berkaitan dengan waktu yang di tempuh. Dalam olahraga sepakbola, kecepatan lari sangat diperlukan untuk mengejar bola dalam menyerang maupun bertahan,

2) Kekuatan dan ketahanan otot kaki

Kekuatan dan ketahanan otot kaki digunakan pada saat menendang, menggiring ,mengumpan,berlari, dalam permainan sepakbola sangat banyak sekali dan sangat diutamakan . kekuatan sangat diperlukan dalam setiap melakukan aktivitas olahraga Kekuatan merupakan komponen yang harus dimiliki oleh setiap pemain sepakbola.

3) Ketahanan dan Kekuatan

Kekuatan adalah kemampuan otot untuk melakukan kontraksi guna membangkitkan ketegangan terhadap suatu ketahanan. Kekuatan otot adalah komponen yang sangat penting untuk meningkatkan kondisi fisik secara keseluruhan. Power otot tungkai juga merupakan salah satu dari bagian otot, maka dapat di artikan sebagai kemampuan dari kumpulan otot tungkai untuk mengerahkan daya maksimal persatuan waktu (Nugroho, 2020)

4) Daya Tahan

Daya tahan otot setempat merupakan kemampuan seseorang dalam mempergunakan suatu kelompok ototnya, untuk berkontraksi terus menerus dalam waktu yang relatif cukup lama dengan beban tertentu.

\section{Futsal}

Futsal adalah permainan bola yang dimainkan oleh dua regu, yang masing masing beranggotakan lima orang. Tujuannya adalah memasukkan bola ke gawang lawan, dengan memanipulasi bola dengan kaki dan 
anggota tubuh lain selain tangan, kecuali posisi kiper. Selain lima pemain utama, setiap regu juga diizinkan memiliki pemain cadangan. Di indonesia Kompetisi futsal resmi tingkat nasional telah diadakan sejak tahun 2008 yang di kelola oleh Badan Futsal Nasional (BFN), lembaga yang khusus didirikan oleh PSSI untuk mengelola Futsal di Indonesia. Saat itu kejuaraan Indonesia Futsal League (IFL) diikuti tujuh klub futsal seluruh provinsi indonesia.

Pada prinsipnya permainan futsal sama dengan permainan sepakbola yakni menerapkan permainan yang teknik, Fisik dan strategi. Dari Segi permainan futsal dan sepakbola sama-sama bertujuan untuk menciptakan dan memasukkan bola/gol sebanyak mungkin. Dan untuk menciptakan gol tersebut aspek teknik, fisik dan strategi sangat diperlukan. Faktor-faktor penentu dapat disebutkan ada tiga faktor penting yaitu : kondisi fisik atau tingkat kesegaran jasmani, ketepatan teknik atau ketrampilan yang dimiliki, dan masalahmasalah lingkungan (Gumantan dan Mahfud, 2020).

Dalam hal Teknik, passing yang akurat, umpan yang baik dan shooting yang kuat dan terarah sangat diperlukan dan dimaksimalkan. Seperti Dalam melakukan tendangan pemain harus memiliki rangkaian gerak yang kompleks dan didukung oleh komponen kondisi fisik dan postur tubuh (Fahrizqi, 2018). Dalam konteks strategi, posisi, penempatan dan skill individu harus bisa dipadukan. Pemahaman strategi yang baik akan samasama menunjang dalam permainan. Pemain futsal harus memiliki kemampuan teknik untuk passing atau mengoper bola. Ketepatan passing atau mengoper bola yang baik, cermat dan tepat pada sasaran akan lebih memudahkan untuk membuat gol ke gawang lawan (Fahrizqi, 2018). Karena permainan futsal menekankan dalam kerjasama tim. Fisik passing support Akan tetapi permainan futsal lebih cepat intensitasnya dibandingkan dengan sepakbola.

Dari segi fisik Pemain futsal diharuskan memiliki kecepatan, kekuatan dan daya tahan yang sangat prima. . segala aspek fisik yang ada harus benar-benar dimiliki setiap pemain futsal. Kemudian, Dalam penjagaan kondisi fisik pemain futsal hendaknya meliputi latihan kelenturan, latihan lari cepat berulang-ulang untuk meningkatkan kemampuan anaerobik, sesi latihan lari secara terus menerus untuk meningkatkan kemampuan jantung dan latihan kekuatan untuk mengembangkan system otot dan tulang (Danny Mielke, 2007). Segi kecepatan pemain futsal harus mempunyai kecepatan yang stabil. Dalam segi Kekuatan, pemain harus memiliki tendangan yang kuat, karena dari kekuatan itu akan menciptakan peluang yang lebih besar dalam membuat sebuah gol. Namun, jika kurangnya latihan fisik berdampak pada power otot tungkai yang lemah, kurangnya kelincahan dan kecepatan (Nugroho, 2020). Dari penjelasan diatas, Beberapa komponen kondisi fisik yang diperlukan dan mempengaruhi kemampuan passing atau mengoper bola, diantaranya yaitu panjang tungkai, kekuatan otot tungkai, lingkar paha kekuatan tung kai,dan koordinasi kaki (Fahrizqi, 2018).

\section{UKM Futsal Teknokrat}

UKM Futsal Universitas Teknokrat Indonesia dibentuk pada tahun 2009 , dibentuknya UKM agar tersalurnya bakat serta prestasi mahasiswa pada saat itu. Terbentuknya UKM Futsal Universitas Teknokrat Indonesia menjadi wadah tersendiri untuk para atlet atau mahasiswa yang memang memiliki ketertatikan serta kemampuan dalam permainan futsal. UKM Futsal Universitas Teknokrat Indonesia telah memiliki banyak Prestasi khusunya di lingkup provinsi sumatera bagian selatan.

Banyak kejuaraan yang telah diikuti dan banyak pula prestasi yang telah diukir oleh UKM. Salah satunya menjadi Juara pada kejuaraan Futsal Se-Sumbagasel yang diadakan di Palembang tahun 2017. Di provinsi Lampung sendiri UKM futsal Universitas Teknokrat Indonesia sudah sering mengikuti kejuaraan yang diadakan baik oleh Pemerintah Provinsi maupun Universitas lainnya. Untuk tingkat nasional prestasi terakhir yang pernah diikuti yakni menjadi peserta nasional pada kejuaraan Pekan Olahraga Mahasiswa Nasional di Yogjakarta tahun 2010 dan di Jakarta tahun 2019.

Dari penjelasan kajian teori diatas dapat disimpulkan dalam permainan futsal pemain harus memiliki kondisi fisik serta kebugaran jasmani yang baik. Untuk itu penjagaan kondisi fisik pemain futsal Ukm Teknokrat Indonesia hendaknya meliputi latihan kelenturan, latihan lari cepat berulang-ulang untuk meningkatkan kemampuan anaerobik, sesi latihan lari secara terus menerus untuk meningkatkan kemampuan jantung dan latihan kekuatan untuk mengembangkan sistem otot dan tulang. 


\section{METODE}

\section{Populasi dan Sampel}

Dalam setiap penelitian, populasi yang dipilih erat kaitannya dengan masalah yang ingin diteliti, populasi adalah obyek/subyek yang mempunyai kualitas dan karakteristik tertentu yang ditetapkan oleh peneliti untuk dipelajari dan ditarik kesimpulan (Sugiono, 2012). Berdasarkan pengertian penelitian di atas maka populasi dalam penelitian ini adalah semua anggota UKM Futsal Universitas Teknokrat Indonesia yang berjumlah 29 orang.

\section{Teknik Pengumpulan Data}

Data yang diperoleh oleh peneliti melalui tes dan pengukuran terhadap Variabel yang terdapat dalam penelitian berupa : Kecepatan, Kekuatan, dan Taya Tahan Aerobik (VO2max). Tes ini terdiri dari (1) Sprint 60 Meter untuk mengukur kecepatan, (2) Tes Vertical Jump, Pull Up dan Sit Up Untuk Mengukur Kekuatan dan (3) Bleep Test untuk mengukur Daya Tahan Aerobik (VO2Max)

\section{Metode Analisis}

Metode yang digunakan pada penelitian ini ialah metode penelitian deskriptif. Menurut (Sugiyono, 2012) penelitian deskriptif yaitu, penelitian yang dilakukan untuk mengetahui nilai variabel mandiri, baik satu variabel atau lebih (independen) tanpa membuat perbandingan, atau menghubungkan dengan variabel yang lain. Pada penelitian ini nantinya akan digambarkan tentang kondisi fisik anggota UKM Futsal Universitas Teknokrat Indonesia.

\section{HASIL DAN PEMBAHASAN}

\section{Hasil}

Secara keseluruhan, diperoleh nilai maksimum sebesar 11 dan nilai minimum 2.11. Rata-rata diperoleh sebesar 16 dan standar deviasi sebesar 2,11. Median diperoleh sebesar 17 dan modus sebesar 17. Selanjutnya data akan disusun dalam distribusi frekuensi sesuai dengan rumus yang ditentukan, yang terbagi menjadi lima kategori yaitu baik sekali, baik, cukup, kurang, dan kurang sekali. Berikut tabel distribusi frekuensi Tingkat Kesegaran Jasmani Anggota UKM Futsal Universitas Teknokrat Indonesia dapat dilihat pada tabel statistik di bawah ini :

Tabel 1. Varians Data Tes Kebugaran Jasmani

\begin{tabular}{|c|c|c|c|c|c|}
\hline & & Frequency & Percent & Valid Percent & Cumulative Percent \\
\hline \multirow[t]{11}{*}{ Valid } & 11,00 & 1 & 3,4 & 3,4 & 3,4 \\
\hline & 13,00 & 2 & 6,9 & 6,9 & 10,3 \\
\hline & 14,00 & 3 & 10,3 & 10,3 & 20,7 \\
\hline & 15,00 & 3 & 10,3 & 10,3 & 31,0 \\
\hline & 16,00 & 5 & 17,2 & 17,2 & 48,3 \\
\hline & 17,00 & 10 & 34,5 & 34,5 & 82,8 \\
\hline & 18,00 & 2 & 6,9 & 6,9 & 89,7 \\
\hline & 19,00 & 1 & 3,4 & 3,4 & 93,1 \\
\hline & 20,00 & 1 & 3,4 & 3,4 & 96,6 \\
\hline & 21,00 & 1 & 3,4 & 3,4 & 100,0 \\
\hline & Total & 29 & 100,0 & 100,0 & \\
\hline
\end{tabular}


Tabel 2. Klasifikasi Hasil Tes Tingkat Kebugaran Jasmani

\begin{tabular}{cclcc}
\hline No & Jumlah Nilai & \multicolumn{1}{c}{ Klasifikasi } & Frekuensi & Persentase \% \\
\hline 1 & $22-25$ & Baik Sekali (BS) & 0 & 0 \\
\hline 2 & $18-21$ & Baik (B) & 5 & $17,24 \%$ \\
\hline 3 & $14-17$ & Sedang (S) & 20 & $68,96 \%$ \\
\hline 4 & $10-13$ & Kurang (K) & 4 & $13,79 \%$ \\
\hline 5 & $5-9$ & Kurang Sekali (KS) & 0 & 0 \\
\hline & Total & 29 & $100 \%$ \\
\hline
\end{tabular}

Berdasarkan tabel di , diperoleh bahwa 5 Anggota (17,24\%) mempunyai tingkat kebugaran jasmani Baik (B), 20 Anggota (68,96\%) mempunyai tingkat kebugaran jasmani Sedang (S), 4 Anggota (13,79\%) mempunyai tingkat kebugaran jasmani Kurang $(\mathrm{K})$. Sehingga dapat disimpulkan bahwa tingkat kesegaran jasmani anggota UKM Futsal Universitas Teknokrat Indonesia berdasar hasil keseluruhan tes mempunyai hasil tes yang berbeda. Jadi dapat disimpulkan bahwa Sebagian besar kebugaran jasmani yang dimiliki oleh anggota UKM Futsal Universitas Teknokrat Indonesia adalah masuk kedalam kategori sedang.

\section{Tes Sprint 60 Meter/Kecepatan}

Hasil analisis data dari indikator Tes Spirnt $60 \mathrm{~m}$ berdasarkan perhitungan Tes Kebugaran Jasmani Indonesia (TKJI) diperoleh data yang berbentuk nilai, kemudian dikategorikan menjadi lima kategori yaitu baik sekali, baik, sedang, kurang, dan kurang sekali. Berikut tabel distribusi frekuensi tingkat kebugaran jasmani anggota UKM Futsal Universitas Teknokrat Indonesia berdasarkan tes Sprint 60 meter, sebagai berikut :

Tabel 3. Klasifikasi Tes Sprint 60 Meter

\begin{tabular}{cclcc}
\hline No & Skor & \multicolumn{1}{c}{ Klasifikasi } & Frekuensi & Persentase \% \\
\hline 1 & $<7,2 ”$ & Baik Sekali (BS) & 0 & 0 \\
\hline 2 & 7,3 “- 8,3 ” & Baik (B) & 3 & $10,4 \%$ \\
\hline 3 & $8,4 ”-9,6 ”$ & Sedang (S) & 24 & $82,75 \%$ \\
\hline 4 & $9,7 ”-11,0 ”$ & Kurang (K) & 2 & $6,9 \%$ \\
\hline 5 & $>11,1 ”$ & Kurang Sekali (KS) & 0 & 0 \\
\hline & Total & 29 & $100 \%$ \\
\hline
\end{tabular}

Berdasarkan tabel di atas, diperoleh bahwa 0 Anggota (0\%) mempunyai kecepatan lari kurang sekali, 2 Anggota (10,4\%) mempunyai kecepatan lari kurang, 24 Anggota (82,75\%) mempunyai kecepatan lari Sedang , 3 Anggota (10,4\%) mempunyai kecepatan lari baik dan 0 Anggota (0\%) mempunyai kecepatan lari baik sekali..

\section{Tes Pull Up}

Hasil analisis data dari indikator Pull Up berdasarkan perhitungan Tes Kebugaran Jasmani Indonesia (TKJI) diperoleh data yang berbentuk nilai, kemudian dikategorikan menjadi lima kategori yaitu baik sekali, baik, sedang, kurang, dan kurang sekali. Berikut tabel distribusi frekuensi tingkat kebugaran jasmani anggota UKM Futsal Universitas Teknokrat Indonesia berdasarkan Tes Pull Up, sebagai berikut :

Tabel 4. Klasifikasi Tes Pull Up

\begin{tabular}{ccccc}
\hline No & Skor & \multicolumn{1}{c}{ Klasifikasi } & Frekuensi & Persentase \% \\
\hline 1 & $>19$ & Baik Sekali (BS) & 0 & 0 \\
\hline 2 & $14-18$ & Baik (B) & 7 & $10,4 \%$ \\
\hline 3 & $9-13$ & Sedang (S) & 19 & $65,5 \%$ \\
\hline 4 & $5-8$ & Kurang (K) & 3 & $24,1 \%$ \\
\hline 5 & $<4$ & Kurang Sekali (KS) & 0 & 0 \\
\hline & Total & 29 & $100 \%$ \\
\hline
\end{tabular}

Dari data tabel diatas, diketahui terdapat 7 anggota yang mempunyai klasifikasi berdasarkan Tes Pull Up dengan kriteria Baik (B), 19 Anggota dengan klasifikasi Sedang (B) dan 3 Anggota dengan klasifikasi Kurang (K). 


\section{Tes Sit Up}

Hasil analisis data dari indikator Tes Sit Up berdasarkan perhitungan Tes Kebugaran Jasmani Indonesia (TKJI) diperoleh data yang berbentuk nilai, kemudian dikategorikan menjadi lima kategori yaitu baik sekali, baik, sedang, kurang, dan kurang sekali. Berikut tabel distribusi frekuensi tingkat kebugaran jasmani anggota UKM Futsal Universitas Teknokrat Indonesia berdasarkan Tes Sit Up, sebagai berikut :

Tabel 5. Klasifikasi Tes Sit Up

\begin{tabular}{cclcc}
\hline No & Skor & \multicolumn{1}{c}{ Klasifikasi } & Frekuensi & Persentase \% \\
\hline 1 & $>41$ & Baik Sekali (BS) & 2 & $6,9 \%$ \\
\hline 2 & $30-40$ & Baik (B) & 11 & $37,9 \%$ \\
\hline 3 & $21-29$ & Sedang (S) & 15 & $51,7 \%$ \\
\hline 4 & $10-20$ & Kurang (K) & 1 & $3,4 \%$ \\
\hline 5 & $>9$ & Kurang Sekali (KS) & 0 & 0 \\
\hline & Total & 29 & $100 \%$ \\
\hline
\end{tabular}

Dari data tabel diatas, diketahui terdapat 2 anggota yang mempunyai klasifikasi berdasarkan Tes Sit Up dengan kriteria Baik Sekali (BS), 11 Anggota dengan klasifikasi Sedang (B) , 15 Anggota dengan klasifikasi Sedang (S) dan 1 Anggota dengan klasifikasi Kurang (K).

\section{Tes Vertical Jump}

Hasil analisis data dari indikator Vertical Jump berdasarkan perhitungan Tes Kebugaran Jasmani Indonesia (TKJI) diperoleh data yang berbentuk nilai, kemudian dikategorikan menjadi lima kategori yaitu baik sekali, baik, sedang, kurang, dan kurang sekali. Berikut tabel distribusi frekuensi Tingkat Kebugaran Jasmani Anggota UKM Futsal Universitas Teknokrat Indonesia berdasarkan Tes Vertical Jump, sebagai berikut :

Tabel 6. Klasifikasi Tes Vertical Jump

\begin{tabular}{cclcc}
\hline No & Skor & \multicolumn{1}{c}{ Klasifikasi } & Frekuensi & Persentase \% \\
\hline 1 & $>73$ & Baik Sekali (BS) & 0 & 0 \\
\hline 2 & $60-72$ & Baik (B) & 9 & $31,0 \%$ \\
\hline 3 & $50-59$ & Sedang (S) & 19 & $65,5 \%$ \\
\hline 4 & $39-49$ & Kurang (K) & 1 & $3,4 \%$ \\
\hline 5 & $<38$ & Kurang Sekali (KS) & 0 & 0 \\
\hline & Total & 29 & $100 \%$ \\
\hline
\end{tabular}

Dari data tabel diatas, diketahui terdapat 9 anggota yang mempunyai klasifikasi berdasarkan Tes Vertical Jump dengan kriteria Baik (B), 19 Anggota dengan klasifikasi Sedang (S) dan 1 Anggota dengan klasifikasi Kurang (K).

\section{Tes lari 1,2 KM (VO2Max)}

Hasil analisis data dari indikator lari 1,2 KM (VO2Max) berdasarkan perhitungan Tes Kebugaran Jasmani Indonesia (TKJI) diperoleh data yang berbentuk nilai, kemudian dikategorikan menjadi lima kategori yaitu baik sekali, baik, sedang, kurang, dan kurang sekali. Berikut tabel distribusi frekuensi tingkat kebugaran jasmani anggota UKM Futsal Universitas Teknokrat Indonesia berdasarkan Tes Lari 1,2 Km (VO2Max), sebagai berikut :

Tabel 7. Klasifikasi Tes Lari 1,2 Km (VO2Max)

\begin{tabular}{cclcc}
\hline No & Skor & \multicolumn{1}{c}{ Klasifikasi } & Frekuensi & Persentase \% \\
\hline 1 & $<3,14 ”$ & Baik Sekali (BS) & 2 & $6,9 \%$ \\
\hline 2 & $3,15 "-4,25 ”$ & Baik (B) & 8 & $27,6 \%$ \\
\hline 3 & $4,26 "-5,12 ”$ & Sedang (S) & 15 & $51,7 \%$ \\
\hline 4 & $5,13 "-6,33 ”$ & Kurang (K) & 4 & $13,8 \%$ \\
\hline 5 & $>6,34$ & Kurang Sekali (KS) & 0 & 0 \\
\hline & Total & 29 & $100 \%$ \\
\hline
\end{tabular}


Dari data tabel diatas, diketahui terdapat 2 anggota yang mempunyai klasifikasi berdasarkan Tes Lari 1,2 Km (VO2Max) dengan kriteria Baik Sekali (BS), 8 Anggota dengan klasifikasi Baik (B) ,15 Anggota dengan klasifikasi Sedang (S) dan 4 Anggota dengan klasifikasi Kurang (K).

\section{Pembahasan}

Melihat hasil Tingkat Kebugaran Jasmani Anggota UKM Futsal Universitas Teknokrat Indonesia secara keseluruhan menunjukkan pengembangan Tingkat kondisi masih belum maksimal. Kemungkinan disebabkan oleh beberapa faktor salah satu diantaranya adalah pelaksanaan latihan. Pemain sebaiknya diberikan program latihan disesuaikan dengan tujuan yaitu untuk meningkatkan kualitas Tingkat Kebugaran Jasmani yang dimiliki oleh pemain. contohnya latihan yang bertujuan untuk meningkatkan kecepatan lari pemain maka program latihan yang dibuat adalah lari dengan waktu yang singkat. Jika latihan tidak di sesuaikan dengan tujuan makatujuan latihan tersebut tidak akan tercapai tepat untuk masing-masing komponen Tingkat Kebugaran Jasmani yang masih tergolong kurang. Faktor lainnya yang juga akan mempengaruhi tingkat kebugaran jasmani anggota UKM Futsal tersebut antara lain : kurangnya beraktifitas jasmani atau latihan diluar jam latihan. Karena dengan Melakukan kegiatan fisik dan olahraga secara baik, teratur dan terus menerus bermanfaat dalam mencapai status kebugaran jasmani yang optimal. Dengan menambah latihan individu maka tubuh juga akan memiliki cukup daya dan akan terlatih dengan baik. Latihan yang baik dan benar akan memberikan pengaruh yang besar pada tiap komponen tubuh dari setiap anggota.dengan pola latihan yang baik dan benar secara tidak langsung akan mempermudah setiap anggota dalam menjalani latihan lutin yang biasanya berat untuk dijalani.

Pola hidup dan lingkungan yang kurang sehat juga berpengaruh. Dengan pola hidup sehat akan berpengaruh terhadap kesegaran jasmani. Kesehatan badan juga dipengaruhi oleh lingkungan yang ada disekitar, baik lingkungan fisik dan lingkungan mental dan sosial. Kebiasaan dalam kegiatan sehari-hari yang kurang pengawasan dari orang tua dalam menjaga kesehatan pribadi, juga lingkungan tempat tinggal yang kurang layak. Banyak anggota yang terpengaruh kedalam lingkungan sosial yang kurang baik seperti begadang, merokok dan minuman keras sehingga akan berpengaruh terhadap kebugaran jasmani dari anggota tersebut.

Untuk mendapatkan kesegaran jasmani yang baik, dibutuhkan antara lain makanan dan gizi, tidur dan istirahat, latihan jasmani dan olahraga, kebiasaan hidup sehat serta lingkungan yang sehat. (Moeloek, 1984). Dengan kesadaran akan menjaga kesehatan tubuh masing masing tentunya bagian lain untuk mempertahankan kebugaran jasmani sebagai pemainatau atlet. Makanan yang sehat akan bisa dengan mudah dicerna oleh tubuh. Fungsi anatomis dan fisiologi tubuh akan lebih mudah bekerja. Karena makanan yang sehat akan memberikan pasokan energi yang baik. Dengan energi yang baik tersebut makan takaran dari energi tubuh yang diperlukan oleh tubuh sehingga bagian terkecil dari tubuh seperti otot dan jaringan akan selalu siap. Karena setiap sel, jaringan dan otot merupakan penyusun dari setiap anggota tubuh.

Kebiasan lain yang sering dilakukan oleh insan olahraga atau atlet yakni tidur larut. Kurangnya tidur tentunya akan sangat merugikan tubuh. Karena tubuh yang sudah terlatih akan menjadi hilang tenaganya saat atlet tersebut begadang. Terlalu sering tidur larut akan membebani tubuh, karena bagian tubuh yang seharusnya bisa diistirahatkan akan bekerja ekstra. Selanjutnya pendapat lain mengemukakan bahwa seseorang dikatakan memiliki kesegaran jasmani apabila orang tersebut mempunyai kekuatan, kemampuan, kesangguan, dan daya tahan untuk melakukan pekerjaannya dengan efisien, tanpa menimbulkan kelelahan yang berarti yaitu sehabis bekerja atau melakukan aktifitas, masih mempunyai cadangan tenaga serta masih dapat menikmati waktu dengan baik (Kosasih, 1981).

\section{SIMPULAN}

Berdasarkan dari hasil penelitian dan pembahasan tersebut, maka dapat simpulkan : Tingkat Kebugaran Jasmani Anggota UKM Futsal Universitas Teknokrat Indonesia, nampak bahwa dari 29 sampel anggota UKM ternyata yang diklasifikasikan Baik sebanyak 5 orang (17,24\%), klasifikasi sedang sebanyak 20 orang $(68,96 \%)$, dan klasifikasi Kurang sebanyak 4 orang (13,79\%), dan tidak ada siswa yang memiliki klasifikasi Baik Sekali dan Kurang Sekali. Dengan demikian, hasil tes tingkat kesegaran jasmani pada Anggota UKM Futsal Universitas Teknokrat Indonesia dapat dikategorikan Sedang. Hal ini disebabkan karena kurangnya aktifitas yang menunjang dalam menjaga kebugaran jasmani seperti kegiatan latihan individu, juga faktor kebersihan, aktifitas olahraga lain, makanan, kebiasaan dan pola hidup serta keadaan lingkungan hidup. 


\section{DAFTAR PUSTAKA}

Cholik, Mutohir, dan Gusril. (2004). Perkembangan motorik pada masa anak- anak. Jakarta

Fahrizqi, Eko Bagus. (2018). Hubungan Panjang Tungkai, Power Tungkai Dan Koordinasi Mata-Kaki Dengan Kemampuan Passing Pada Pemain Unit Kegiatan Mahasiswa Olahraga Futsal Perguruan Tinggi Teknokrat. Journal of S.P.O.R.T 2. (1). 32-43

Gumantan, Aditya. Mahfud, Imam (2018). Perbandingan Latihan Dengan Menggunakan Bola Ukuran 4 Dan 5 Terhadap Ketepatan Menendang Bola Ke Arah Gawang. Journal of S.P.O.R.T. 2 (1). 1-7

Giriwijoyo, S. dkk. (2007). Ilmu Kesehatan Olahraga. Bandung

Kosasih, Engkos, (1981), Olahraga dan Kesehatan. BPK Gunung Mulia, Jakarta

Lutan. Rusli (1991). Belajar Keterampilan, Pengantar Teori dan Metode. Jakarta

Mahfud, Imam. Fahrizqi, Eko Bagus .(2020) Pengembangan Model Latihan Keterampilan Motorik Melalui Olahraga Tradisional Untuk Siswa Sekolah Dasar. Sport Science And Education Journal.1(1). 31-37

Mielke, Danny. (2007). Dasar-Dasar Sepak Bola. Label: 796.334 MIE a. Penerbit: Bandung: Pakar Raya

Moeloek D, Tjokronegoro (1984). Dasar Fisiologi Kesegaran Jasmani dan Latihan Fisik, Kesehatan dan Olahraga Universitas Indonesia, Jakarta

Nugroho, Reza Adhi. Gumantan, Aditya. Pengaruh Latihan Plyometric Terhadap Peningkatan Kemampuan Vertical Jump Peserta Ekstrakurikuler Bolabasket Sman 1 Pagelaran. Sport Science And Education Journal Universitas Teknokrat Indonesia. 1(1). 1-12

Sajoto, M. (1988). Pembinaan Kondisi Fisik Dalam Olahraga. Depdikbud irektorat Jendral Pendidikan Tinggi Proye Pengembangan LPTK, Jakarta

Sugiyono. (2012). Metode Penelitian Kuantitatif Kualitatif dan R\&D. Bandung: Alfabeta

Yuliandra, Rizki. (2018). Pengembangan Model Latihan Jump Shoot Bola Basket. Journal of S.P.O.R.T. 2(1). 51-55

\section{BIOGRAFI PENULIS}

Muhammad Vani Aprilianto,
saat ini sedang menempuh Pendidikan Ssarjana (Strata-1) di Universitas
Teknokrat Indonesia dengan mengambil Program Studi Pendidikan Olahraga
angkatan 2017. Penulis juga merupakan Asisten Dosen di Program Studi.
Penulis dapat dihubungi melalui Email : m.vaniaprilianto.2015@gmail.com

